\title{
The Diagnostic Value of CA19.9 in Predicting the Resectability of Pancreatic Cancer
}

\author{
ABDELGHANY M. ELSHAMY, M.D.; MOHAMED A. ABD ELHAMID, M.D. and \\ AHMED I.A. IBRAHIM, M.Sc. \\ The Department of General Surgery, Faculty of Medicine, Ain Shams University
}

\begin{abstract}
Background: Pancreatic Ductal Adenocarcinoma (PDAC) is one of the deadliest cancers presenting an increased mortality rate of about $3 \%$ of all cancers and about $7 \%$ of all cancer death in the United States and Europe. One of them, used for long as potential independent predictor of surgery is the Sialylated Lewis blood group carbohydrate antigen 19.9 (CA19.9). CA19.9 is detected in low levels in healthy individuals (up to $37 \mathrm{U} / \mathrm{ml}$ ) and the level is elevated in several types of cancers including pancreatic, and also in benign conditions such as pancreatitis and choledocholithiasis.
\end{abstract}

Aim of Study: To evaluate the diagnostic value of CA19.9 in predicting the resectability of pancreatic cancer.

Patients and Methods: This is prospective and retrospective study which was carried out on 25 patients diagnosed as patients with biopsy-proved adenocarcinoma of the pancreas. All patients were selected from Eldemerdash Hospital University, Ain-Shams University Hospitals in the period from January 2016 to April 2019.

Results: The majority of the patients have cancer head of pancreas $(72 \%)$, while $20 \%$ were confined to the body and $8 \%$ were confined to the body and tail. The majority of patients (44\%) underwent pancreaticoduodenectomy, $20 \%$ of patients underwent distal pancreatectomy, $4 \%$ of patients underwent total pancreatectomy, and $32 \%$ patients underwent only exploratory laparotomy and biopsy. At present the best way for pre-operative staging of pancreatic cancer is bolous and triphase helical computed tomography, which have been showen to be almost $100 \%$ accurate in predicting unresectable disease. Serum CA19.9 level in patients with unresectable tumor was highly significantly higher compared with that in patients with resectable tumor. Positive significant correlation between CA19-9 with total bilirubin, ALT and AST.

Conclusion: CA19.9 is one of the tumor markers for pancreatic adenocarcinoma. It can be used as marker to identify pancreatic adenocarcinoma with limited sensitivity and specificity. The use of CA19.9 in conjunction with modern imaging techniques may improve the characterization of resectability and categorization of 'borderline-resectable' tumours, however this biomarker alone does not possess

Correspondence to: Dr. Ahmed Ibrahim Ali Ibrahim, E-Mail: sharqawy d@yahoo.com enough predictive value. Most likely, as suggested by many others, a combination of biomarkers is needed in order to achieve acceptable sensitivity and specificity in a disease with non-specific symptoms and low incidence.

Key Words: Carbohydrate antigen 19.9 - Endoscopic retrograde cholangiopancreatography - Magnetic resonance cholangiopancreatography - Magnetic resonance imaging.

\section{Introduction}

PANCREATIC cancer is the most lethat solid organ malignancies. It represents the 11 most common cancer in the United Kingdom, accounting for $3 \%$ of all new cancer cases. Pancreatectomy offers the only potential for cure but it is only possible in minority of patient even in these patients who undergo resection [1].

Pancreatic cancer affects males more than females. The tumor peak incidence lies between 55 and 70 years of age.

The prognosis of pancreatic cancer is extremely poor and its early diagnosis is difficult, still surgical resection offers the best chance of cure [2] .

At present the best way for pre-operative staging of pancreatic cancer is bolus and tri-phase helical computed tomography, which have been showing to be almost $100 \%$ accurate in predicting unresectable disease [3].

CA19.9 is the most common tumors markers used for diagnosis or monitor pancreatic malignancies [4].

CA19.9 more useful for monitoring of recurrence following curative surgery rather than for diagnosis [5]. 
The sensitivity and specificity of CA19.9 for diagnosis of pancreatic malignancies varies from 70-90\% [6].

Serum CA19.9 may also elevated at other condition such as cholangio carcinoma and chronic pancreatitis [7].

Aim of the work:

The aim of the study is to evaluate the diagnostic value of CA19.9 in predicting the resectability of pancreatic cancer.

\section{Patients and Methods}

The current study represents prospective and retrospective study which was carried out on 25 patients diagnosed as patients with biopsy-proved adenocarcinoma of the pancreas. All patients were selected from El-Demerdash Hospital University, Ain-Shams University Hospitals in the period from January 2016 to April 2019.

The study protocol: The study protocol was approved by Faculty of Medicine, Ain Shams University, Research Ethics Committee. Informed written consents were taken before inclusion of the patients into the study after explanation of the technique, expectations, possible side effects and alternative treatments.

Patients: Age of the study population ranged from $45-<85$ years with and (64\%) of them were males. Were recruited in the study.

\section{Methods assay:}

Serum samples were stored at $-20 \sim$ to $-70 \sim C$, and these specimens were then assayed within 1 week. The CA 19.9 concentration was determined by a solid phase radioimmunoassay (Centocor, Inc., Malvern, $\mathrm{Pa}$ ).

A value of $37 \mathrm{U} / \mathrm{ml}$ was used as the upper limit of normal. One unit of CA 19.9 antigen corresponds to $0.8 \mathrm{ng} / \mathrm{ml}$ of pure antigen.

Chemiluminescent microparticle immunoassayCMIA: All immunoassays require the use of the labeled material in order to measure the amount of antigen or antibody. A label is a molecule that will react as a part of the assay, so a change in signal can be measured in the blood after adding reagent solution. CMIA is noncompetitive sandwich assay technology to measure analyses. The amount of signal is directly proportional to the amount of analytic present in the sample. Architect CA 19.9 assay is two-step immunoassay to determine the presence CA 19.9 in human serum using CMIA technology.
In the first step, sample, assay diluent and antiCA 19.9-antibody-coated paramagnetic particles are combined. CA 19.9, present in the sample, binds to the anti-CA 19.9 coated micro particles. After incubation and wash, anti-CA 19.9-acridinium-labeled conjugate is added in the second step. Following another incubation and wash, pretrigger and trigger solutions are then added to the reaction mixture. The pre-trigger solution (hydrogen peroxide) creates an acidic environment to prevent the early release of energy (light emission), helps to keep micro particles from clumping and splits acridinium dye off the conjugate bound to the micro particle complex (this action prepares the acridinium dye for the next step). The trigger solution (sodium hydroxide) dispenses to the reaction mixture. The acridinium undergoes an oxidative reaction when is exposed to peroxide and an alkaline solution. This reaction causes the occurrence of the chemiluminescent reaction. N-methylacridone forms and releases energy (light emission) as it returns to its ground state. The resulting chemiluminescent reaction is measured as Relative Light Units (RLU). A direct relationship exists between the amount of CA 19.9 in the sample and RLU detected by Architect System optics.

Radiological assessment: Abdominal ultrasound. Pancreatic protocol CT and MRI were done. ERCP was done when necessary.

Administrative considerations: An official permission was obtained from Ain-Shams University Hospital. An official permission was obtained from the Osteology Department. An official permission was obtained from the Institutional Research. Approval from Ethical Committee in the Faculty of Medicine (Institutional Research Board IRB).

Ethical consideration: Informed consent was obtained from all participants after being informed about the aims and process of the study as well as applicable objectives. The study procedures were free from any harmful effects on the participants as well as the service provided. The principal investigators have kept individual data as private information safely.

\section{Data management and statistical analysis:}

Data entry, processing and statistical analysis was carried out using using SPSS version 20 (Statistical Package for the Social Sciences). Tests of significance (Kruskal-Wallis, Wilcoxon's, Chi square, logistic regression analysis, and Spearman's correlation) were used. Data were presented and suitable analysis was done according to the type of data (parametric and non-parametric) obtained 
for each variable. $p$-values less than $0.05(5 \%)$ was considered to be statistically significant.

$p$-value: Level of significance: $p>0.05$ : NonSignificant (NS). $p<0.05$ : Significant (S). $p<0.01$ : Highly Significant (HS).

Descriptive statistics: Mean, Standard Deviation $( \pm$ SD) and range for parametric numerical data, while median and Inter-Quartile Range (IQR) for

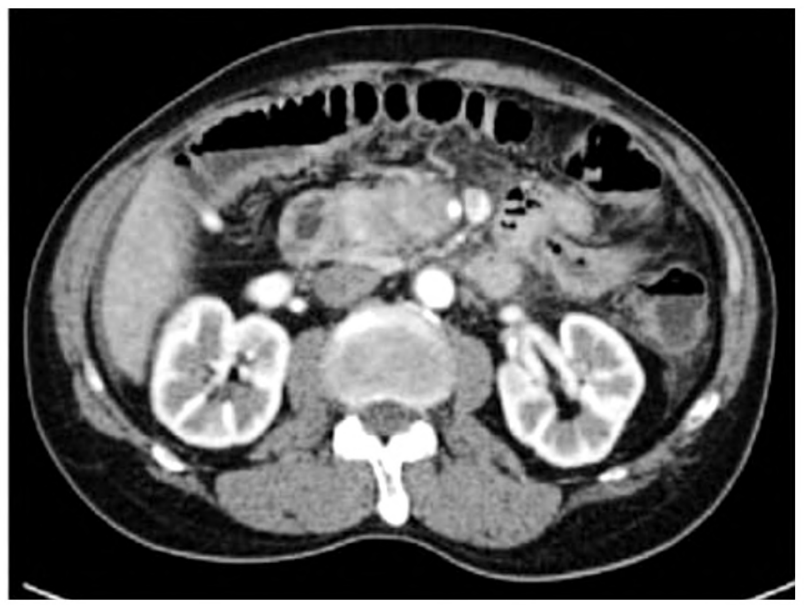

non-parametric numerical data. Frequency and percentage of non-numerical data.

\section{Analytical statistics:}

Kruskal-Wallis test was used to assess the statistical significance of the difference of a nonparametric variable between more than two study groups.

\section{Results}

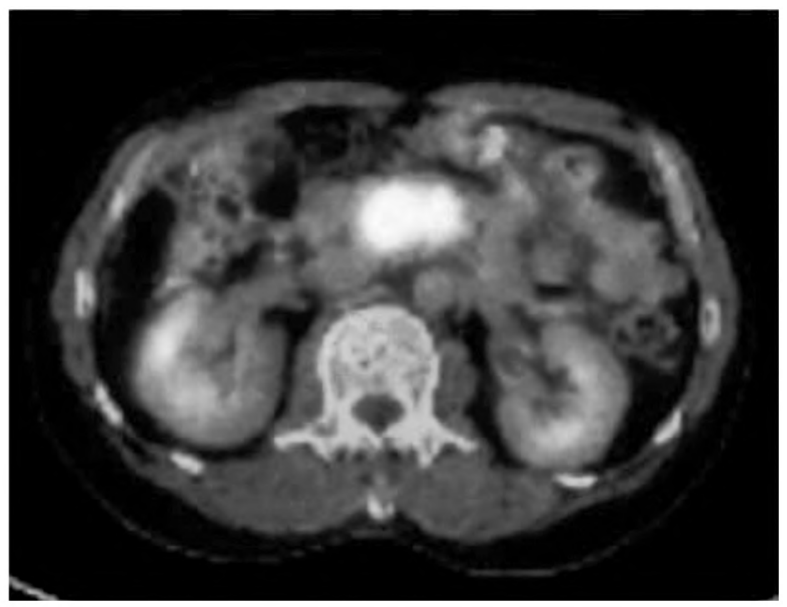

Fig. (1): Shows C.T and PET scan of pancreatic cancer.
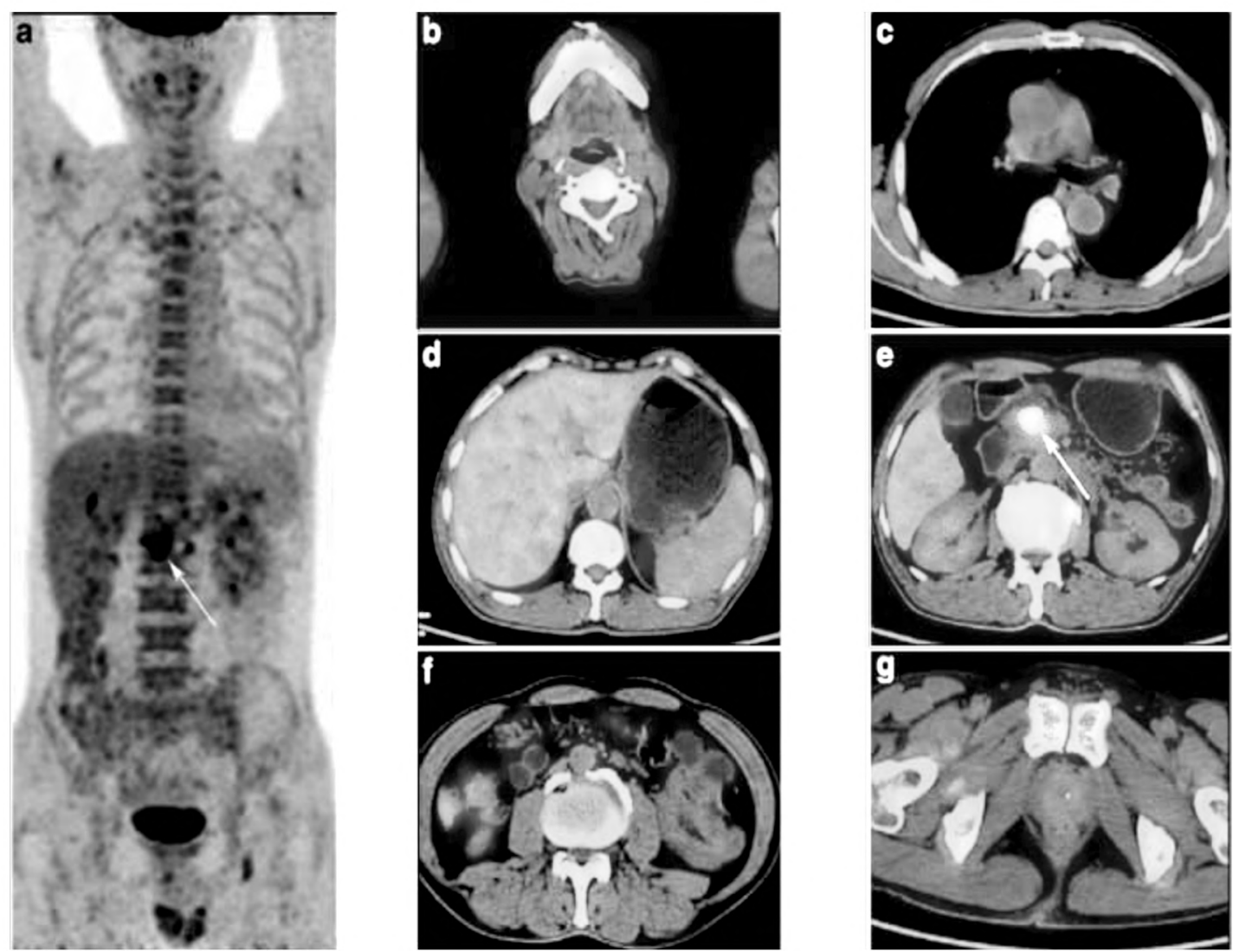

Fig. (2): Showing 59 years old male patient with pancreatic cancer (A) PET/C.T fusion, (E) Images show a mass in the pancreatic head increased FDG uptake (arrow). 


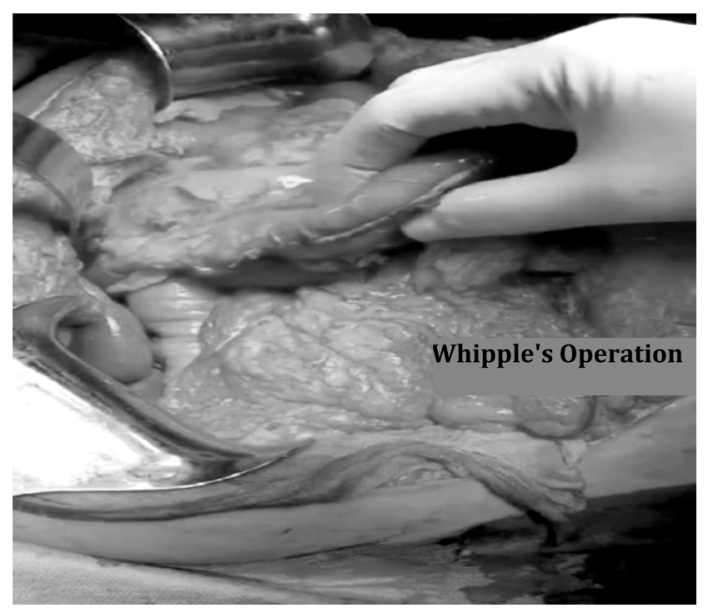

Fig. (3): Showing reconstruction after resection during the Whipple's operation for treatment of pancreatic head cancer.

Table (1): Showing age of the study groups ranged from 45 years to $<85$ years.

\begin{tabular}{llllll}
\hline & Age & N & $p \%$ & M & S.D \\
\hline 1 & a $45-<55$ & 5 & 20 & 50.2 & 3.89 \\
2 & a $55-<65$ & 5 & 20 & 60.6 & 3.64 \\
3 & a $65-<75$ & 10 & 40 & 70.2 & 2.65 \\
4 & a $75-<85$ & 5 & 20 & 68.2 & 5.16 \\
\hline & Total & 25 & $100 \%$ & & \\
\hline
\end{tabular}

Table (2): Showing sex of patients 16 patients are male and 9 patients are female.

\begin{tabular}{lllllr}
\hline & Gender & $\mathrm{N}$ & $p \%$ & \multicolumn{1}{c}{$\mathrm{M}$} & S.D \\
\hline 1 & Male & 16 & 64 & 1.36 & 0.489 \\
2 & Female & 9 & 36 & $(\mathrm{M}=1, \mathrm{~F}=2)$ & \\
\hline & Total & 25 & $100 \%$ & & \\
\hline
\end{tabular}

Table (3): Showing location of the tumors in all patients.

\begin{tabular}{llllll}
\hline & Location of tumor & $\mathrm{N}$ & $p \%$ & $\mathrm{M}$ & S.D \\
\hline 1 & Head & 18 & 72 & 1.32 & 0.637 \\
2 & Body & 5 & 20 & head & \\
3 & Body and tail & 2 & 8 & & \\
\hline & Total & 25 & $100 \%$ & & \\
\hline
\end{tabular}

Table (4): Showing types of operations in patients with pancreatic cancers.

\begin{tabular}{|c|c|c|c|c|}
\hline Operations & $\mathrm{N}$ & $p \%$ & M & S.D \\
\hline $\begin{array}{l}\text { 1 } \text { Pancreaticoduodenectomy } \\
2 \cdot \text { Distal pancreatectomy } \\
3 \cdot \text { Total pancreatectomy } \\
4 \cdot \text { Exploratory laparotomy } \\
\quad \text { and biopsy }\end{array}$ & $\begin{array}{l}11 \\
5 \\
1 \\
8\end{array}$ & $\begin{array}{l}44 \\
20 \\
4 \\
32\end{array}$ & $\begin{array}{l}1.2 \\
\text { pancr- } \\
\text { eaticoduo- } \\
\text { denectomy }\end{array}$ & 1.33 \\
\hline Total & 25 & $100 \%$ & & \\
\hline
\end{tabular}

Table (5): Showing pancreatic cancers classification according to C.T pancreatic protocol.

\begin{tabular}{lllcc}
\hline \multicolumn{1}{c}{ Pancreatic cancer } & $\mathrm{N}$ & $p \%$ & $\mathrm{M}$ & S.D \\
\hline 1 Resectable & 10 & 40 & 1.24 & 1.23 \\
2 Borderline & 5 & 20 & Resectable & \\
3 Locally advanced & 4 & 16 & & \\
4 Metastatic & 6 & 24 & & \\
\hline \multicolumn{1}{c}{ Total } & 25 & $100 \%$ & & \\
\hline
\end{tabular}

Table (6): Showing borderline pancreatic tumors after surgery.

\begin{tabular}{|c|c|c|c|c|}
\hline & $\begin{array}{l}\text { Borderline pancreatic } \\
\text { cancer }\end{array}$ & $\mathrm{N} \boldsymbol{p} \%$ & M & S.D \\
\hline 1 & $\begin{array}{l}\text { - Resectable Borderline } \\
\text { pancreatic cancer }\end{array}$ & & $\begin{array}{l}1.6 \\
\text { Unresectable }\end{array}$ & 0.547 \\
\hline \multirow[t]{2}{*}{2} & $\begin{array}{l}\text { - Unresectable } \\
\text { Borderline pancreatic } \\
\text { cancer }\end{array}$ & $360 \mathrm{Bc}$ & $\begin{array}{l}\text { orderline } \\
\text { pancreatic } \\
\text { cancer }\end{array}$ & \\
\hline & Total & $5 \quad 100 \%$ & & \\
\hline
\end{tabular}

Table (7): Showing pancreatic tumors classification according to its operability.

\begin{tabular}{llllll}
\hline & Pancreatic cancer & $\mathrm{N}$ & $p \%$ & \multicolumn{1}{c}{$\mathrm{M}$} & $\mathrm{S} . \mathrm{D}$ \\
\hline 1 & Operable & 1248 & 1.52 & 0.509 \\
2 & Non operable & 1352 & non operable & \\
\hline & Total & 25 & $100 \%$ & & \\
\hline
\end{tabular}

Table (8): Showing operable pancreatic cancer.

\begin{tabular}{|c|c|c|c|c|c|}
\hline & $\begin{array}{l}\text { Pancreatic tumor } \\
\text { - operable }\end{array}$ & $\mathrm{N}$ & $p \%$ & $\mathrm{M}$ & S.D \\
\hline 1 & $\begin{array}{l}\text { - Resectable pancreatic } \\
\text { cancer }\end{array}$ & 10 & 83.34 & $\begin{array}{l}1.16 \\
\text { Resectable }\end{array}$ & 0.389 \\
\hline 2 & $\begin{array}{l}\text { - Resectable Borderline } \\
\text { pancreatic cancer }\end{array}$ & 2 & 16.66 & $\begin{array}{l}\text { pancreatic } \\
\text { cancer }\end{array}$ & \\
\hline & Total & 12 & $100 \%$ & & \\
\hline
\end{tabular}

Table (9): Showing non operable pancreatic cancer.

\begin{tabular}{|c|c|c|c|c|c|}
\hline & $\begin{array}{l}\text { Pancreatic tumor } \\
\text { - Non operable }\end{array}$ & $\mathrm{N}$ & $p \%$ & M & S.D \\
\hline 1 & $\begin{array}{l}\text { - Unresectable borderline } \\
\text { pancreatic cancer }\end{array}$ & \multicolumn{2}{|c|}{323.08} & $\begin{array}{l}2.23 \\
\text { Locally }\end{array}$ & \multirow[t]{3}{*}{0.832} \\
\hline 2 & $\begin{array}{l}\text { - Locally advanced } \\
\text { pancreatic cancer }\end{array}$ & 4 & 30.77 & $\begin{array}{l}\text { advanced } \\
\text { pancreatic }\end{array}$ & \\
\hline 3 & - Metastatic & 6 & 46.15 & cancer & \\
\hline & Total & 13 & 100 & & \\
\hline
\end{tabular}


Table (10): Showing relationship between CA19.9 and its operability.

\begin{tabular}{|c|c|c|c|c|c|c|c|}
\hline Total of pt & Pancreatic cancer & CA19.9 & M & S.D & $\mathrm{F}$ & DF & Sig. \\
\hline 10 & Resectable pancreatic cancer & $<150 \mathrm{u} / \mathrm{ml}$ & 136.2 & 1.932 & 222.910 & 9 & 0.000 \\
\hline 2 & Resectable borderline pancreatic cancer & $150-<300 \mathrm{u} / \mathrm{ml}$ & 229 & 9.899 & 1.101 & 1 & 0.419 \\
\hline 3 & Unresectable borderline pancreatic cancer & $300-<450 \mathrm{u} / \mathrm{ml}$ & 330.6 & 15.885 & 1.055 & 2 & 0.240 \\
\hline 4 & Locally advanced pancreatic cancer & $500-<1000 \mathrm{u} / \mathrm{ml}$ & 770.2 & 173.338 & 8.887 & 3 & 0.000 \\
\hline 6 & Metastatic & $>1000 \mathrm{u} / \mathrm{ml}$ & 2587.1 & 881.405 & 7.190 & 5 & 0.000 \\
\hline
\end{tabular}

Table (11): Comparison between CA19.9, and total and direct bilirubin and liver enzymes in the studied groups.

\begin{tabular}{|c|c|c|c|c|c|c|}
\hline Total of pt & Pancreatic cancer & CA19.9 & Total Bilirubin & Direct Bilirubin & ALT & AST \\
\hline $10 \mathrm{pts}$ & $\begin{array}{l}\text { - Resectable pancreatic } \\
\text { cancer }\end{array}$ & $\begin{array}{l}<150 \mathrm{u} / \mathrm{ml}: \\
\mathrm{M}=136.2 \\
\mathrm{SD}=1.932\end{array}$ & $\begin{array}{l}1.5-2.5 \mathrm{mg} / \mathrm{dL}: \\
\mathrm{M}=2.19 \\
\mathrm{SD}=0.334\end{array}$ & $\begin{array}{l}1-2.5 \mathrm{mg} / \mathrm{dL}: \\
\mathrm{M}=2.11 \\
\mathrm{SD}=0.445\end{array}$ & $\begin{array}{l}\text { 10-20u/l: } \\
\mathrm{M}=16.8 \\
\mathrm{SD}=2.936\end{array}$ & $\begin{array}{l}10-15 \mathrm{u} / \mathrm{l}: \\
\mathrm{M}=12.3 \\
\mathrm{SD}=1.059\end{array}$ \\
\hline $2 \mathrm{pts}$ & $\begin{array}{l}\text { - Resectable borderline } \\
\text { pancreatic cancer }\end{array}$ & $\begin{array}{l}150-<300 \mathrm{u} / \mathrm{ml}: \\
\mathrm{M}=229 \\
\mathrm{SD}=9.899\end{array}$ & $\begin{array}{l}5-7 \mathrm{mg} / \mathrm{dL}: \\
\mathrm{M}=6 \\
\mathrm{SD}=1.414\end{array}$ & $\begin{array}{l}3-6 \mathrm{mg} / \mathrm{dL}: \\
\mathrm{M}=4.5 \\
\mathrm{SD}=2.121\end{array}$ & $\begin{array}{l}15-25 \mathrm{u} / \mathrm{l} \\
\mathrm{M}=20 \\
\mathrm{SD}=7.071\end{array}$ & $\begin{array}{l}5-25 u / 1: \\
M=20.5 \\
S D=6.363\end{array}$ \\
\hline $3 \mathrm{pts}$ & $\begin{array}{l}\text { - Un resectable borderline } \\
\text { pancreatic cancer }\end{array}$ & $\begin{array}{l}300-<450 \mathrm{u} / \mathrm{ml}: \\
\mathrm{M}=330.6 \\
\mathrm{SD}=15.885\end{array}$ & $\begin{array}{l}10-12 \mathrm{mg} / \mathrm{dL}: \\
\mathrm{M}=11 \\
\mathrm{SD}=1\end{array}$ & $\begin{array}{l}8-12 \mathrm{mg} / \mathrm{dL}: \\
\mathrm{M}=10 \\
\mathrm{SD}=1.732\end{array}$ & $\begin{array}{l}30-45 u / 1: \\
M=36.6 \\
S D=7.637\end{array}$ & $\begin{array}{l}20-40 u / l: \\
M=32.3 \\
S D=10.785\end{array}$ \\
\hline $4 \mathrm{pts}$ & $\begin{array}{r}\text { - Locally advanced } \\
\text { pancreatic cancer }\end{array}$ & $\begin{array}{l}500-<1000 \mathrm{u} / \mathrm{ml}: \\
\mathrm{M}=770.2 \\
\mathrm{SD}=173.338\end{array}$ & $\begin{array}{l}15-18 \mathrm{mg} / \mathrm{dL}: \\
\mathrm{M}=16.75 \\
\mathrm{SD}=1258\end{array}$ & $\begin{array}{l}10-15 \mathrm{mg} / \mathrm{dL}: \\
\mathrm{M}=13 \\
\mathrm{SD}=2.160\end{array}$ & $\begin{array}{l}100-150 \mathrm{u} / \mathrm{l}: \\
\mathrm{M}=131.75 \\
\mathrm{SD}=22.306\end{array}$ & $\begin{array}{l}80-130 u / 1: \\
M=115.75 \\
S D=23.893\end{array}$ \\
\hline $6 \mathrm{pts}$ & - Metastatic & $\begin{array}{l}>1000 \mathrm{u} / \mathrm{ml}: \\
\mathrm{M}=2587.1 \\
\mathrm{SD}=881.405\end{array}$ & $\begin{array}{l}20-25 \mathrm{mg} / \mathrm{dL}: \\
\mathrm{M}=23.16 \\
\mathrm{SD}=1.722\end{array}$ & $\begin{array}{l}16-20 \mathrm{mg} / \mathrm{dL}: \\
\mathrm{M}=18.166 \\
\mathrm{SD}=1.471\end{array}$ & $\begin{array}{l}\text { 200-250u/l: } \\
\mathrm{M}=232 \\
\mathrm{SD}=19.005\end{array}$ & $\begin{array}{l}150-300 \mathrm{u} / \mathrm{l} \\
\mathrm{M}=221.6 \\
\mathrm{SD}=55.966\end{array}$ \\
\hline
\end{tabular}

\section{Discussion}

Pancreatic cancer is one of the most lethal solid organ malignancies, with a 5-year survival rate of $6 \%$. It represents the 11 th most common cancer in the United Kingdom, accounting for 3\% of all new cancer cases. It is characterized by diagnostic difficulty, distant metastasis and aggressive local invasion at an early stage [8] .

Pancreatic cancer affects males more than females. The tumor peak incidence lies between 55 and 70 years of age. The prognosis of pancreatic cancer is extremely poor and its early diagnosis is difficult [9].

The only way to cure pancreatic cancer is to remove the entire tumor with no residual disease (microscopic resection-margin negative). A preoperative assessment for the possibility of complete resection for patients with pancreatic cancer is very important because precise estimation results in fewer unnecessary operations that do not afford survival benefit to the patients [1] .

Even in those patients who undergo resection, most die because occult extrapancreatic metastatic disease was likely present at the time of diagnosis [10].
Currently, the study of choice for pre-operative staging of pancreatic cancer is Computed Tomography (CT). The accuracy of thin-cut, bolus-contrast, triple phase helical CT in predicting inoperability approaches $100 \%$; however, the determination of resectability is only $75 \%$ to $80 \%$ [11].

CA19.9 is detected in low levels in healthy individuals (up to $37 \mathrm{U} / \mathrm{ml}$ ) and the level is elevated in several types of cancers including pancreatic, and also in benign conditions such as pancreatitis and choledocholithiasis [12].

CA19.9 is the most common tumor marker used for diagnosis and monitoring of pancreatic malignancies in which CA19.9 is reported to have a sensitivity ranging between $68 \%$ and $92 \%$. Its measurement is simple, fast, cheap and noninvasive [5]

Utility of CA19.9 in pancreatic cancer has been explored for screening, diagnostic, prognosis, predictive and also resectability purposes. Preoperative CA19.9 levels are associated with cancer staging and prognosis. Increased values are associated with the identification of unresectable disease during staging laparoscopy or laparotomy [13] .

The use of CA19.9 values is known to influence the decision of pancreatic cancer surgery. However, 
still for years, controversy has existed in regard the clinical cut-off of CA19.9 levels to determine resectability [14].

In the present study, the majority of patients had cancer head of pancreas 18 patients $(72 \%)$, while 5 patients $(20 \%)$ were confined to the body and 2 patients $(8 \%)$ were confined to the body and tail.

The majority of patients, 11 patients (44\%) underwent pancreaticoduodenectomy, 5 patients (20\%) of patients underwent distal pancreatectomy, 1 patients (4\%) of patients underwent total pancreatectomy, and 8 patients (32\%) patients underwent only exploratory laparotomy and biopsy.

Herrero s-Villanueva et al., [14] showed that, out of 203 patients included in their study tumor was localized in the head of pancreas in 138 patients (68\%), body-tail in 20 patients (30\%) and was not defined in 4 patients $(2 \%)$. TNM clinical staging was I in $24(11.8 \%)$ patients, II in $26(12.8 \%)$, III in $48(23.6 \%)$, IV in $94(46.3 \%)$ and unknown in $11(5.5 \%)$.

Among 25 patients included in the present study, C.T with pancreatic protocol has been done, $10(40 \%)$ of them had resectable tumor and 5 patients (20\%) had borderline pancreatic tumor. While, 4 patients $(16 \%)$ had locally advanced pancreatic cancer and 6 patients (24\%) had metastasis.

Herreros-Villanueva et al., [14] reported that 43 (21.2\%) out of the 203 patients were considered resectable while 160 patients $(78.8 \%)$ were considered unresectable. Out of the 43 resectable patients, 35 patients were curative and 8 with exploratory intent.

In Herrero s-Villanueva et al., [14], CA19.9 values were only available in $176(86.7 \%)$ of the patients. The mean value of CA19.9 was $4793 \pm$ $16,878 \mathrm{U} / \mathrm{ml}$ and median of $309.7 \mathrm{U} / \mathrm{ml}(95 \% \mathrm{CI}$ 2282-7304). Among the 176 patients, CA19.9 was normal $(\leq 37 \mathrm{U} / \mathrm{ml})$ in $50(28.4 \%)$ and elevated $(>37$ $\mathrm{U} / \mathrm{ml})$ in $126(71.6 \%)$. Significant differences were found between CA19.9 serum values between resectable and non resectable patients.

American Society of Clinical Oncology Clinical practice guideline [15] recommend surgical resection of the primary tumor and lymph nodes for patients with CA19.9 suggestive of potentially curable disease, but in absence of jaundice.
In the present study, there was a positive significant correlation between CA19.9 with total bilirubin, ALT and AST.

Also, in Herreros-Villanueva et al., [14], 26.6\% of patients, presented jaundice at diagnosis; no correlation exists between CA19.9 and jaundice.

Identified that CA19.9 serum levels are not markedly affected by hyperbilirubinemia in both pancreatic cancer as well as chronic pancreatitis (correlation coefficients $\leq 0.135$ ).

A study published in 2017 by Mirkin et al., [16] found an association between pre-treatment CA19.9 levels $>800 \mathrm{U} / \mathrm{ml}$ and advanced stage disease.

In 2018, Santucci et al., [17] reported CA19.9 levels over $178 \mathrm{U} / \mathrm{ml}$ strongly suggest unresectable disease. This yielded a sensitivity of $87.7 \%$ and specificity of $81.6 \%$.

Hartwig et al., [18] reported the usefulness of preoperative CA19.9 levels based on results from a cohort of more than 1600 patients with potentially resectable PDAC and investigated the correlation between CA19.9 levels and tumor resectability. In pre-operative levels more than $500 \mathrm{U} / \mathrm{ml}$, the resectability ratio was less than $70 \%$ and the median survival time after pancreatectomy was less than 20 months.

Herreros-Villanueva et al., [14], demonstrated a limited clinical utility of 500U/ml for CA19.9 as it provided only a sensitivity of $55.56 \%$ and a specifcity of $72.72 \%$.

In Veldhuisen et al., [19], 54 patients with Locally Advanced Pancreatic Cancer (LAPC) after induction chemotherapy, using a 30\% decrease of CA19.9 as cut-off, 9/10 patients were correctly classified as resectable (90\% sensitivity, PPV $43 \%$ ) and $3 / 15$ as unresectable (20\% specificity, NPV $75 \%$ ). A CA19.9 decrease $\geq 30 \%$ was associated with improved survival (22.4 vs. 12.7 months, $p=0.02$ ).

In Kim et al., [20], the mean and median values of CA19.9 for resectable tumors were significantly lower than unresectable tumors. The best cut-off points for CA19.9, and tumor size to predict resectability were $92.77 \mathrm{U} / \mathrm{mL}$ and $11.85 \mathrm{~cm}^{3}$, respectively. A CA19.9 $\geq 92.77 \mathrm{U} / \mathrm{mL}$ and value no less than the cut-off level predicted the possibility of unresectability with $90.6 \%$ accuracy. However, tumor marker less than the cut-off levels predicted the probability of resection only with $40.6 \%$ accuracy. 
The use of CA19.9 in conjunction with modern imaging techniques may improve the (I) Characterization of resectability, (II) Categorization of 'borderline-resectable' tumours and (III) Selection of patients for neoadjuvant systemic therapy.

The most important limitation is lack of consensus between different studies with different cutoff values of CA19.9; further homogenous studies are urgently needed.

Furthermore, the utility of CA19.9 has several confounding limitations. Patients, who are negative for the Lewis blood group antigen form approximately $4 \%$ to $15 \%$ of the general population, do not synthesize CA 19.9. We did not test for Lewis antigen status in our study. Only one-half of cancers less than $2 \mathrm{~cm}$ are associated with an elevated CA 19.9. In addition, false-positive elevations in $\mathrm{CA}$ 19.9 exist in benign conditions, such as in patients with extrahepatic biliary obstruction caused by pancreatitis and choledocholithiasis.

\section{Conclusion:}

CA19.9 is one of the tumor markers for pancreatic adenocarcinoma. It can be used as marker to identify pancreatic adenocarcinoma with limited sensitivity and specificity. The use of CA19.9 in conjunction with modern imaging techniques may improve the characterization of resectability and categorization of 'borderline-resectable' tumours, however this biomarker alone does not possess enough predictive value. Most likely, as suggested by many others, a combination of biomarkers is needed in order to achieve acceptable sensitivity and specificity in a disease with non-specific symptoms and low incidence.

The CA19.9 level may be a useful marker for determining pre-operatively which patients have unresectable pancreatic cancer. Even though it is not the main target of this study. The presence of an elevated CA19.9 level should direct the surgeon to more liberal use of staging laparoscopy.

Pre-operative CA19.9 serum levels provide important prognostic information in pancreatic cancer patients, correlate with tumor stage and independently predict overall survival. An increasing post-operative CA19.9 serum level or failure of the CA19.9 serum levels to normalize postoperatively is associated with a poor prognosis and suggests residual disease or the presence of occult metastasis while a decline or normalization of the post-operative CA19.9 serum level is associated with improved survival.

\section{References}

1- VINCENT A., HERMAN J., SCHULICK R., HRUBAN R.H. and GOGGINS M.: Pancreatic cancer. The lancet, 378 (9791): 607-20, 2011.

2- EL-GENDI A.M. and EL-GENDI S.: Influence of standardized histopathological workup on reporting of the resection margin status in pancreatic head cancer. The Egyptian Journal of Surgery, 33 (3): 131, 2014.

3- WAKABAYASHI H., NISHIYAMA Y., OTANI T., SANTO T., YACHIDA S., OKANO K., et al.: Role of 18FFLURO-DEOXY Glucose positron emission tomograohy imaging in surgey for pancreatic cancer world Gastero enteral, 2008.

4- CHUNG K.H., RYU J.K., LEE B.S., JANG D.K., LEE S.H. and KIM Y.T.: Early decrement of serum carbohydrate antigen 19-9 predicts favorable outcome in advanced pancreatic cancer. Journal of gastroenterology and hepatology, 31 (2): 506-12, 2016.

5- REITZ D., GERGER A., SEIDEL J., KORNPRAT P., SAMONIGG H., STOTZ M., SZKANDERA J. and PICHLER M.: Combination of tumour markers CEA and CA199 improves the prognostic prediction in patients with pancreatic cancer. Journal of clinical pathology, 68 (6): 427-33, 2015.

6- ALEXAKIS N., GOMATOS I.P., SBAROUNIS S., TOUTOUZAS K., KATSARAGAKIS S., ZOGRAFOS G. and KONSTANDOULAKIS M.M.: High serum CA 19-9 but not tumor size should select patients for staging laparoscopy in radiological resectable pancreas head and periampullary cancer. European Journal of Surgical Oncology (EJSO), 41 (2): 265-9, 2015.

7- BAGHDADY, F. FOUAD, M. SAYED, A. SHOAIB, Y. SALAH, E. ELSHAYEB and A. EFAT HASAN: Serum markers for the early detection of hepatocellular carcinoma in patients with chronic viral hepatitis. Menoufia Med. J., 27: 544-50, 2014.

8- SIEGEL R.L., MILLER K.D. and JEMAL A.: Cancer statistics, 2016. CA: A cancer journal for clinicians, 66 (1): 7-30, 2016.

9- FERLAY J., SOERJOMATARAM I., ERVIK M., DIKSHIT R., ESER S., MATHERS C., REBELO M., PARKIN D.M., FORMAN D. and BRAY F.L.: France: International Agency for Research on Cancer; 2013. Cancer Incidence and Mortality Worldwide: IARC Cancer Base, 10, 2012.

10- DUCREUX M., CARAMELLA C., HOLLEBECQUE A., BURTIN P., GOÉRÉ D., SEUFFERLEIN T., HAUSTERMANS K., VAN LAETHEM J.L., CONROY T. and ARNOLD D.: Cancer of the pancreas: ESMO Clinical Practice Guidelines for diagnosis, treatment and follow-up. Annals of Oncology, 26 (suppl-5): v56-68, 2015.

11-SAHANI D.V., SHAH Z.K., CATALANO O.A., BOLAND G.W. and BRUGGE W.R.: Radiology of pancreatic adenocarcinoma: Current status of imaging. Journal of gastroenterology and hepatology, 23 (1): 23-33, 2008.

12- KARANDISH F. and MALLIK S.: Biomarkers and targeted therapy in pancreatic cancer. Biomarkers in cancer, 8: 34414, 2016. 
13- GOH S.K., GOLD G., CHRISTOPHI C. and MURALIDHARAN V.: Serum carbohydrate antigen 19-9 in pancreatic adenocarcinoma: A mini review for surgeons. ANZ journal of surgery, 87 (12): 987-92, 2017.

14- HERREROS-VILLANUEVA M., RUIZ-REBOLLO L., MONTES M., RODRIGUEZ-LOPEZ M., FRANCISCO M., CUBIELLA J., IYO E., GARABITOS E., MONEO E.M., MARTOS M. and De MADARIA E.: CA19-9 capability as predictor of pancreatic cancer resectability in a Spanish cohort. Molecular Biology Reports, 1-6, 2020.

15- American Society of Clinical Oncology Clinical practice guideline, 2016.

16- MIRKIN K.A., HOLLENBEAK C.S. and WONG J.: Prognostic impact of carbohydrate antigen 19-9 level at diagnosis in resected stage I-III pancreatic adenocarcinoma: A US population study. Journal of gastrointestinal oncology, 8 (5): 778, 2017.

17- SANTUCCI N., FACY O., ORTEGA-DEBALLON P., LEQUEU J.B., RAT P. and RAT P.: CA 19-9 predicts resectability of pancreatic cancer even in jaundiced patients. Pancreatology, 18 (6): 666-70, 2018.

18- HARTWIG W., STROBEL O., HINZ U., FRITZ S., HACKERT T., ROTH C., BÜCHLER M.W. and WERNER J.: CA19-9 in potentially resectable pancreatic cancer: Perspective to adjust surgical and perioperative therapy. Annals of surgical oncology, 20 (7): 2188-96, 2013.

19- VELDHUISEN E., VOGEL J.A., KLOMPMAKER S., BUSCH O.R., VAN LAARHOVEN H.W., VAN LIENDEN K.P., WILMINK J.W., MARSMAN H.A. and BESSELINK M.G.: Added value of CA19-9 response in predicting resectability of locally advanced pancreatic cancer following induction chemotherapy. HPB, 20 (7): 605-11, 2018.

20- KIM Y.C., KIM H.J., PARK J.H., PARK D.I., CHO Y.K., SOHN C.I., JEON W.K., KIM B.I. and SHIN J.H.: Can pre-operative CA19-9 and CEA levels predict the resectability of patients with pancreatic adenocarcinoma? Journal of gastroenterology and hepatology, 24 (12): 1869-75, 2009. 


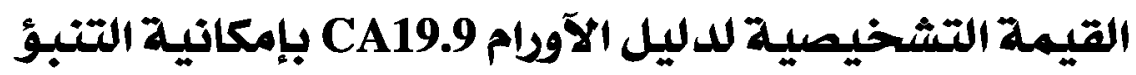 عن سرطان البنكرياس القابل لإلاستئصال الجرامراحى}

يعتبر سرطان البنكرياس واحد من آكثر السرطانات المميتة وهو يمثل بّ٪ من معدل الوفيات من بين السرطانات الآخرى ويسبب الوفاة

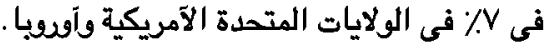

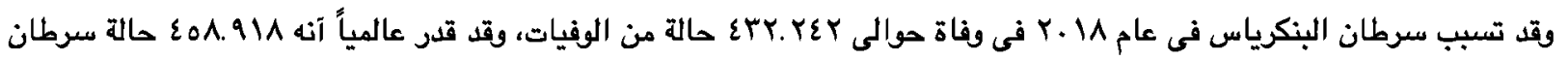

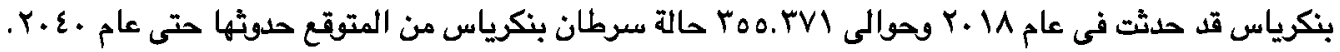

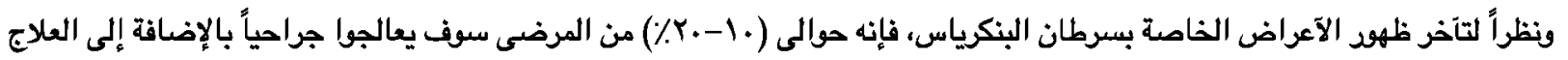

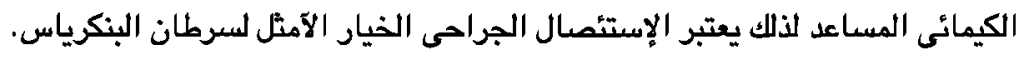

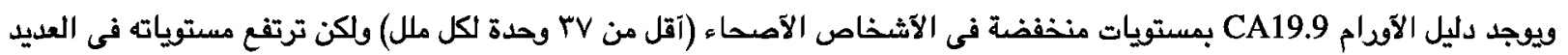

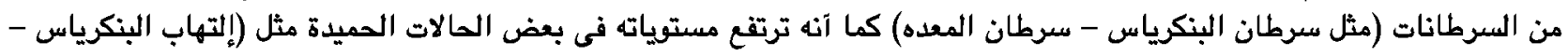

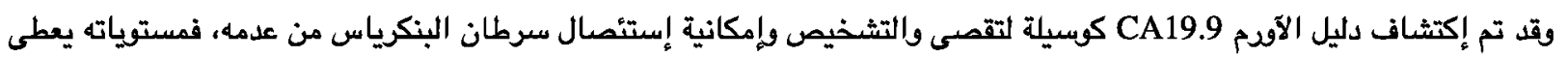

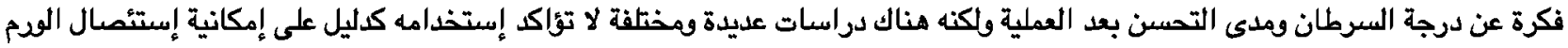

من علدمه

الهدف من هذه الدراسة هى معرفة القيمة التشخيصية لدليل الآوام CA19.9 فى القدرة على التنبئ بسرطان البنكرياس القابل للإستئمال الجراحى.

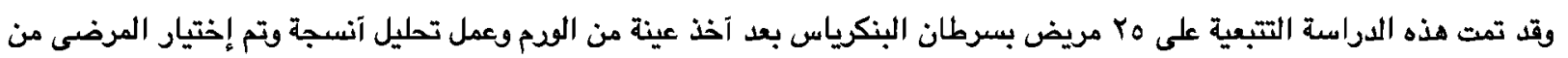

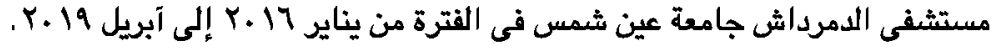

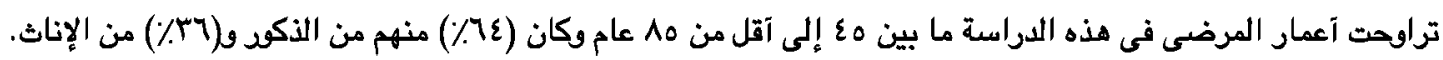

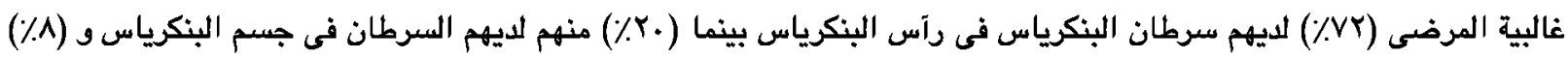
محصوين فى الجسم والذيل.

غالبية المرضى (ع ع٪) تم إستئصال سرطان البنكرياس والإثثى عشر (عملية ويلز) بينما (.ب٪) من هم خضعوا للإستئصال البنكرياس

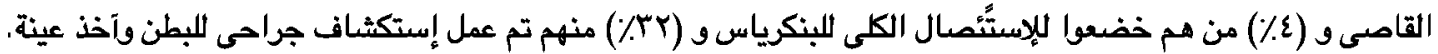

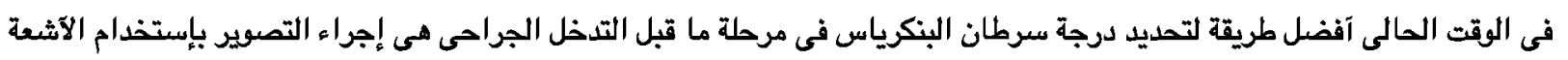
متعددة المقاطع بالصبغة وثلاثية الآبعاد والتى آثتبتت آنها دقيقة ـ. ـ٪ فى التتبؤ بسرطان البنكرياس الغير قابل للإستئصال الجراحى. مستوى دليل الآودام CA19.9 فى مرضى سرطان البنكرياس الغير قابل للإستئصال الجراحى آعلى بكثير مقارنة بمرضى سرطان البنكرياس القابل للإستئمال الجراحي. توجد علاقة إيجابية بين دليل الآودام CA19.9 والبليروبين الكلى وإنزيمات الكبد (ALT - AST). 